\title{
ANALISIS PENGARUH PENDIDIKAN DAN PEKERJAAN TERHADAP PENGETAHUAN PRODUK PERBANKAN SYARI'AH (Studi Kasus Kepala Keluarga di Dukuh Krapyak Kulon, Panggungharjo, Sewon, Bantul, Yogyakarta Tahun 2013)
}

\author{
Musyafiq Hasyim dan Abdullah Salam \\ Prodi Ekonomi Syariah STIA Alma Ata Yogyakarta \\ Email: musyafiqhasyiem@yahoo.co.id
}

\begin{abstract}
This study aims to determine the effect of education (educational status) and employment (job status) to the knowledge of shari'ah banking products households in Padukuhan/Krapyak Dukuh Kulon, Panggungharjo, Sewon, Bantul, Yogyakarta. sThe population in this study was 917 heads offamilies that are recorded in card family in Padukuhan/Dukuh Kulon Krapyak Pangoungharjo, Sewon, Bantul, Yogyakarta. The sample in this study is taken by the method $10-15 \%$ of the population and should not be less than $10 \%$ of total sample of 95 respondents. Results of t test analysis shows that each of the independent variables significantly influence the knowledge of banking products shari'ah. In the F test showed that the independent variables have a significant effect. The determinansi coefficient $\left(R^{2}\right)$ of 0.173 , which means knowledge of banking products shari'ah in Padukuhan Krapyak Kulon able to be explained by the independent variables of $17.3 \%$ and the remaining $82.7 \%$ is influenced by other variables outside of this research model.
\end{abstract}

Keyword: Education, Job Status, The Knowledge of Syari'ah Banking Product

\section{PENDAHULUAN}

Perkembangan perbankan syari'ah di Indonesia dimulai pada periode tahun 1970 dimana pada tahun tersebut muncul gagasan pendirian Bank Syari'ah dan keberadaan perbankan Islam di tanah air telah mendapatkan pijakan kokoh setelah lahirnya Undang-undang Perbankan nomor 7 Tahun 1992, yang isinya tentang bank bagi hasil dan saat itu pula berdiri Bank Muamalat Indonesia (Alma, Donni 2009). Kemudian diikuti oleh BPR Syari'ah Bangun Drajad Warga dan BPR Syari'ah Margi Rizki Bahagia yang keduanya berada di Yogyakarta, kemudian undang-undang tersebut direvisi melalui Undang-undang Nomor 10 tahun 1998, yang dengan tegas mengakui keberadaan dan berfungsinya Bank Bagi Hasil atau Bank Islam dengan prinsip syari'ah (Muhammad, 2005).

Produk perbankan syari'ah menerapkan prinsip yang konsisten berdasarkan tuntunan Al-Qur'an dan Hadits yang membawa pada kebaikan dunia dan kebahagian di akhirat nanti, pada sistem operasi bank syari'ah, pemilik dana menanamkan uangnya di bank tidak dengan motif 
mendapatkan bunga, tapi dalam rangka mendapatkan keuntungan bagi hasil secara adil yang tidak bersandarkan pada bunga atau mengikuti ketentuanketentuan syari'ah. Oleh karena itu masyarakat harus memiliki pengetahuan terhadap produk perbankan syari' ah agar mereka terhindar dari bunga yang diterapkan oleh Bank Konvensional(Alma, Donni 2009).

Masyarakat khususnya kepala keluarga yang berada di Dukuh Krapyak Kulon, Desa Panggungharjo, Kecamatan Sewon, Kabupaten Bantul, Daerah Istimewa Yogyakarta ini merupakan suatu masyarakat yang memiliki berbagai latar belakang pendidikan dan pekerjaan yang berbeda-beda serta kental akan nilai-nilai islaminya, dimana di Dukuh Krapyak Kulon terdapat Pondok Pesantren Krapyak Yogyakarta yang sudah berdiri sejak lama. Oleh karena itu masyarakat di Dukuh Krapyak Kulon ini dijadikan sebagai subjek penelitian tentang pengetahuan masyarakat terhadap produk perbankan syari' ah dengan objek penelitiannya di Dukuh Krapyak Kulon, Panggungharjo, Sewon, Bantul, Yogyakarta.

Berdasarkan hal-hal yang ditunjukan diatas penulis memilih judul penelitian"Analisis Pengaruh Pendidikan dan Pekerjaan Terhadap Pengetahuan Produk Perbankan Syari'ah"

\section{METODOLOGI PENILITIAN}

Jenis penelitian ini adalah penelitian deskriptif kuantitatif yakni penelitiannya didasarkan pada data-data berupa angka-angka, sehingga diperoleh mean, simpangan baku (Machfoed 2010). Penelitian ini dirancang dengan menggunakan pendekatan cross-sectional. Pendekatan cross-sectional, artinya penelitian ini didalam pengumpulan datanya dilakukan dengan satu periode waktu tertentu, setiap subjek, studinya hanya satu kali pengamatan selama penelitian, maksudnya ketika memberikan kuesioner hanya satu kali saja dan tidak dilakukan ulangan (Husein 2005). Subjek penelitian yang digunakan dalam penelitian ini adalah kepala keluarga yang berada di Dukuh Krapyak Kulon, Panggungharjo, Sewon, Bantul, Yogyakarta yang tercatat dalam kartu keluarga.

Populasi dalam penelitian ini adalah semua kepala keluarga yang sudah memiliki kartu kelurga/tercatat sebagai kepala keluarga di Dukuh Krapyak Kulon, Panggungharjo, Sewon, Bantul, Yogyakarta dengan jumlah 917 kartu Kartu Keluarga (KK). Penentuan besar sampel yang dibutuhkan untuk keperluan penelitian ini yaitu tidak boleh kurang dari 10\% dari jumlah populasi' atau 10-15\% dari 917 Kartu Keluarga (KK). Dalam penelitian ini besar sampelnya yaitu 95 orang. Lokasi penelitian yaitu di Dukuh Krapyak Kulon, Sewon, Bantul, Yogyakarta yang terdiri dari beberapa $3 \mathrm{Rw}$ dan 12 RT. Waktu penelitian pada bulan Juli 2013 sampai dengan September 2013.

\section{Variabel Penelitian}

Dalam penelitian ini terdapat dua variabel penelitian, yaitu: a. Variabel bebas $(X)$ yaitu variabel yang mempengaruhi atau yang menjadi sebab perubahan atau timbulnya variabel dependen (terikat) atau variabel yang nilainya tidak tergantung pada variabel lain, adapun menjadi variabel bebas dari penelitian ini adalah (Husein 2005): 1. Pendidikan (X1) yaitu merupakan faktor yang mempengaruhi tingkat pengetahuan dimana apabila semakin tinggi pendidikan seseorang maka tingkat pengetahuannya akan baik. 2 . Pekerjaan (X2) yaitu merupakan status pekerjaan seseorang dalam keseharian

Musyafiq $\mathrm{H}$. Abdullah Salam

JURNAL EKONOMI SYARIAH INDONESIA, Volume V, No.1 Juni 2015 
untuk mendapatkan penghasilan/uang. b. Variabel Terikat $(Y)$ yaitu variabel yang dipengaruhi atau yang menjadi akibat, karena adanya variabel bebas serta variabel yang nilainya tergantung pada variabel lain atau varibel yang dipengaruhi oleh variabel lainnya. Adapun yang menjadi variabel terikat dalam penelitian ini adalah pengetahuan produk perbankan syari'ah.

Variabel-variabel penelitian ini diukur dengan menggunakan model skala (likert) yang memungkinkan masyarakat/responden dapat menjawab pertanyaan dari setiap butir yang di cantumkan. Penelitian memberikan lima alternatif jawaban kepada responden, maka skala yang digunakan 1 sampai 5 . Adapun skor dari setiap pertanyaan yang terdiri dari skor 5: Sangat Setuju, 4: Setuju, 3: Ragu- ragu, 2: Tidak setuju, 1: Sangat Tidak Setuju.

\section{TEKNIK PENGUMPULAN DATA}

\section{Observasi}

Metode observasi merupakan suatu studi yang sistematis dan yang dipertimbangkan dengan baik melalui panca indra terhadap peristiwaperistiwa yang terjadi pada saat itu (Hadi, 1996).

\section{Kuesioner}

Instrument atau alat pengumpulan data adalah alat atau fasilitas yang digunakan oleh peneliti dalam mengumpulkan data agar pekerjaannya lebih mudah dan hasilnya lebih baik dalam arti lebih cermat, lengkap dan sistematis sehingga lebih mudah diolah (Husein, 2005). Dalam peneletian ini menggunakan metode angket (Quesioner $=$ kuisioner atau daftar pertanyaan) atau sejumlah pertanyaan secara tertulis yang akan dijawab oleh responden penelitian agar peneliti memperoleh data lapangan/empiris untuk memecahkan masalah penelitian dan menguji hipotesis yang telah ditetapkan.

Dalam pengumpulan data ini peneliti menggunakan kuesioner dengan jenis kuesioner tertutup yaitu responden tinggal menjawab pilihan pertanyaan yang telah ditentukan (Sangat Setuju, Setuju, Ragu-ragu, Tidak Setuju atau Sangat TidakSetuju). Setiap kuesioner dilampiri inform consent (surat pernyataan) sebagai bentuk kesediaan menjadi responden.

\section{KEABSAHAN DATA}

Data akan valid apabila nasabah dalam mengisi quesioner bersifat obyektif dan memahami pertanyaan yang ada. Nasabah yang dijadikan sampel pengambilan data dapat dipercaya dengan mengisi dengan sejujurjujurnya untuk menjawab masing-masing butir pertanyaan.

\section{PENGOLAHAN DAN ANALISIS DATA}

\section{Analisis Deskriptif}

Metode analisis deskriptif merupakan cara merumuskan dan menafsirkan data yang ada sehingga memberikan gambaran yang jelas mengenai kaadaan yang nyata tentang pengaruh pendidikan dan pekerjaan masyararakat

Analisis terhadap tingkat pengetahuan produk perbankan syari' ah di Dukuh Krapyak Pengaruh Kulon, Panggungharjo, Sewon, Bantul, Yogyakarta. 


\section{Uji Validitas}

Uji validitas di gunakan untuk mengetahui kelayakan butir-butir dalam suatu daftar (konstruk) pertanyaan dalam mendifinisikan suatu variabel. Daftar pertanyaan ini pada umumnya mendukung suatu kelompok variabel tertentu. Jumlah butir pertanyaan dalam suatu variabel yang pertanyaannya dikatakan valid jika nilai r-hitung yang merupakan nilai dari Corrected ItemTotal Correlation > r-tabel. Validitas juga merupakan suatu ukuran yang menunjukkan tingkat-tingkat kevalidan atau kesahihan suatu instrument. Suatu instrument yang valid atau sahih mempunyai validitas tinggi. Uji validitas juga digunakan untuk mengukur valid tidaknya suatu kuesioner. Suatu kuesioner dikatakan valid jika pertanyaan pada kuesioner mampu untuk mengungkapkan suatu yang akan diukur oleh kuesioner tersebut (Ghozali, 2006). Jikavaliditas tinggi, maka data yang ada akan menunjukkan tidak adanya penyimpangan (Arikunto, 2002). Sebaliknya, instrument yang kurang valid berarti memiliki validitas rendah. Tinggi rendahnya validitas instrument menunjukkan sejauh mana data yang terkumpul tidak menyimpang dari gambaran tentang validitas yang dimaksud. Pengolahan data menggunakan SPSS 16.0 for Windows yaitu dengan cara klik Analyze lalu klik Correlate lalu klik Bivariate kemudian masukan semua item data kemudian klik Ok

\section{Uji Reliabel}

Reliabel artinya dapat dipercaya untuk digunakan sebagai alat pengumpul data karena instrument tersebut sudah baik (Arikunto 2002). Uji reliabilitas dalam penelitian ini adalah menggunakan Cronbach alpha yang berguna untuk mengetahui apakah alat ukur yang dipakai reliabel (handal). Dalam pengolahan data menggunakan SPSS 16.0 for Windows yaitu dengan cara klik Analyze lalu klik Scale lalu klik Reliability Analysis lalu masukan data yang akan diolah kemudian klik Ok.

Kriteria pengambilan keputusannya adalah:

Jika nilai $\mathrm{r}$ hitung $>\mathrm{r}$ tabel maka item dapat dikatakan reliabel.

$\mathrm{r}$ hitung < r tabel maka item dapat dikatakan tidak reliabel. Jika cronbach's alpha $>0,60$ maka dinyatakan reliabel.

\section{Regresi linier berganda}

Adalah suatu analisis yang digunakan untuk mengetahui bagaimana pengaruh dua variabel independen $(X)$ terhadap satu variabel dependen $(Y)$, yang dinyatakan dengan persamaan:

Rumus regresi berganda:

$$
\mathrm{Y}=\mathrm{a}+\mathrm{b}_{1} \mathrm{X}_{1}+\mathrm{b}_{2} \mathrm{X}_{2}
$$

Keterangan:

$\mathrm{Y}=$ Pengetahuan Produk Perbankan Syari'ah

$\mathrm{X}_{1}=$ Pendidikan

$\mathrm{X} 2$ = Pekerjaan

a $=$ Nilai Konstanta

b = Koefesien Regresi

Musyafiq $\mathrm{H}$.

Abdullah Salam

JURNAL EKONOMI SYARIAH INDONESIA, Volume V, No.1 Juni 2015 


\section{Pengujian hipotesis sebagai berikut:}

\section{Uji-t (uji parsial)}

Melalui uji-t (uji parsial) dengan menggunakan langkah-langkah sebagai berikut:

Ho : bi $=0$

Artinya secara parsial tidak terdapat pengaruh yang positif dan signifikan terhadap variabel dependen.

Ha : bi $\neq 0$

Artinya secara parsial terdapat pengaruh yang positif dan signifikan dari variabel independen terhadap variabel dependen.

Kriteria Pengambilan Keputusan (KPK)

Ho diterima jika t-hitung < t-tabel pada $\alpha=5 \%$ Ho ditolak jika t-hitung > t-tabel pada $\alpha=5 \%$ Ha diterima jika t-hitung $>\mathrm{t}$-tabel pada $\alpha=5 \%$ Ha ditolak jika t-hitung $<$ t-tabel pada $\alpha=5 \%$

Jika koefisien signifikan X1,X1 < 0,05 maka signifikan.

\section{Uji-F (uji serentak)}

Uji-F (uji serentak) adalah untuk melihat apakah variabel independen secara bersama-sama (serentak) berpengaruh secara positif dan signifikan terhadap variabel dependen. Melalui uji statistik dengan langkah-langkah sebagai berikut:

Ho : b1, b2 =0

Artinya secara bersama-sama (serentak) tidak terdapat pengaruh yang positif dan signifikan dari variabel independen terhadap variabel dependen.

Ha : b1, b2 $\neq 0$

Artinya secara bersama-sama (serentak) terdapat pengaruh yang positif dan signifikan dari variabel independen terhadap variabel dependen. Kriteria Pengambilan Keputusan (KPK) atau penarikan kesimpulan berdasarkan probabilitas, jika tingkat signifikannya $(\alpha)>0,05$ maka semua variabel independen tidak berpengaruh signifikan terhadap perubahan variabel dependen. Jika tingkat signifikannya $(\alpha)<0,05$ maka semua variabel independen berpengaruh signifikan terhadap nilai perubahan nilai variabel dependen.

\section{Identifikasi determinan}

Identifikasi determinan $\left(R^{2}\right)$ berfungsi untuk mengetahui signifikansi variabel maka harus dicari koefesiensi determinan $\left(R^{2}\right)$. koefesiensi determinan menunjukkan besarnya kontribusi variabel independen terhadap variabel dependen. Semakin besar nilai koefesien determinasi, maka semakin baik kemampuan variabel independen menerangkan variabel dependen. Jika determinasi $\left(R^{2}\right)$ semakin besar (mendekati satu), maka dapat dikatakan bahwa pengeruh variabel independen adalah besar terhadap variabel dependen. Hal ini berarti, model yang digunakan semakin kuat untuk menerangkan pengaruh variabel independen yang diteliti terhadap variabel dependen. Sebaliknya jika determinan $\left(\mathrm{R}^{2}\right)$ semakin kecil (mendekati nol), maka dapat

Analisis dikatakan bahwa pengaruh variabel independen terhadap variabel dependen Pengaruh semakin kecil. Hal ini berarti, model yang digunakan tidak kuat untuk menerangkan pengaruh variable independen terhadap variabel dependen. 


\section{HASIL PEMBAHASAN}

\section{Uji Validitas}

Pengujian validitas dilakukan dengan menggunakan SPSS 16.0 fo Windows dengan kriteria sebagai berikut:

Jika $r$ hitung positif jika $r$ hitung $>r$ tabel maka pernyataan tersebut valid.

Jika $r$ hitung negatif dan $r$ hitung $<r$ tabel maka pernyataan tersebut tidak valid.

Dalam pengujian validitas ini peneliti menguji 30 responden untuk menguji apakah alat ukur yang digunakan sudah valid dan mempu mengungkapkan suatu yang akan diukur oleh kuesioner. Peneliti melakukan uji coba dengan 30 responden artinya besar $r$ tabelnya yaitu 0,361 pada signifikansi 5\%, sedangkan 0,463 pada signifikansi 1\% (Arikunto, 2002).

\section{Correlations}

Tabel 1. Validitas Pernyataan Satu Sampai Dengan Empat

\begin{tabular}{|c|c|c|c|c|c|c|}
\hline & & $\begin{array}{c}\text { Pernyataan } \\
1\end{array}$ & $\begin{array}{c}\text { Pernyataan } \\
2\end{array}$ & $\begin{array}{c}\text { Peryataan } \\
3\end{array}$ & $\begin{array}{c}\text { Pernyataan } \\
4\end{array}$ & Total \\
\hline Pernyataan & Pearson Correlation & 1 & $.728^{* *}$ & $.393^{*}$ & .273 & $.840^{* *}$ \\
\hline \multirow[t]{2}{*}{1} & Sig. (2-tailed) & & .000 & .032 & .144 & .000 \\
\hline & $\mathrm{N}$ & 30 & 30 & 30 & 30 & 30 \\
\hline \multicolumn{2}{|c|}{ Pernyataan Pearson Correlation } & $.728^{* *}$ & 1 & $.484 * *$ & $.396^{*}$ & $.881^{* *}$ \\
\hline \multirow[t]{2}{*}{2} & Sig. (2-tailed) & .000 & & .007 & .030 & .000 \\
\hline & $\mathrm{N}$ & 30 & 30 & 30 & 30 & 30 \\
\hline \multirow{3}{*}{$\begin{array}{l}\text { Pernyataan } \\
3\end{array}$} & Pearson Correlation & $.393^{*}$ & $.484^{* *}$ & 1 & .225 & $.675^{\star *}$ \\
\hline & Sig. (2-tailed) & .032 & .007 & & .232 & .000 \\
\hline & $\mathrm{N}$ & 30 & 30 & 30 & 30 & 30 \\
\hline \multirow{3}{*}{$\begin{array}{l}\text { Pernyataan } \\
4\end{array}$} & Pearson Correlation & .273 & $.396^{*}$ & .225 & 1 & $.595^{\star *}$ \\
\hline & Sig. (2-tailed) & .144 & .030 & .232 & & .001 \\
\hline & $\mathrm{N}$ & 30 & 30 & 30 & 30 & 30 \\
\hline \multirow[t]{3}{*}{ Total } & Pearson Correlation & $.840^{* *}$ & $.881^{* *}$ & $.675^{* *}$ & $.595^{* *}$ & 1 \\
\hline & Sig. (2-tailed) & .000 & .000 & .000 & .001 & \\
\hline & $\mathrm{N}$ & 30 & 30 & 30 & 30 & 30 \\
\hline
\end{tabular}

**. Correlation is significant at the 0.01 level (2-tailed).

*. Correlation is significant at the 0.05 level (2-tailed).

(Sumber : Olah data kuesioner SPPS for Windows)

Dari tabel di atas $r$ hitung terletak pada kolom total "Person Correlation" pernyataan dinyatakan valid jika nilai $r$ hitung lebih besar dari $r$ tabel, untuk responden dengan jumlah $30 \mathrm{r}$ tabelnya adalah 0,463 pada taraf signifikansi $1 \%$, sedangkan $\mathrm{r}$ hitung untuk semua pernyataan lebih besar dari pada $\mathrm{r}$ table, maka dapat dinyatakan pernyataan 1 (satu) sampai dengan 4 (empat) dapat dinyatakan valid.

Musyafiq H.

Abdullah Salam

JURNAL EKONOMI SYARIAH INDONESIA, Volume V, No.1 Juni 2015 
Tabel 2. Validitas Pernyataan Lima Sampai Dengan Delapan

\section{Correlations}

\begin{tabular}{|c|c|c|c|c|c|c|}
\hline & & $\begin{array}{c}\text { Pernyataan } \\
5\end{array}$ & $\begin{array}{c}\text { Pernyataan } \\
6\end{array}$ & $\begin{array}{c}\text { Pernyataan } \\
7\end{array}$ & $\begin{array}{c}\text { Pernyataan } \\
8\end{array}$ & Total \\
\hline \multirow{3}{*}{$\begin{array}{l}\text { Pernyataan } \\
5\end{array}$} & Pearson Correlation & 1 & $.766^{* *}$ & $.694^{* *}$ & $.762 * *$ & $.900 * *$ \\
\hline & Sig. (2-tailed) & & .000 & .000 & .000 & .000 \\
\hline & $\mathrm{N}$ & 30 & 30 & 30 & 30 & 30 \\
\hline \multirow{3}{*}{$\begin{array}{l}\text { Pernyataan } \\
6\end{array}$} & Pearson Correlation & $.766 * *$ & 1 & $.668 * *$ & $.756 * *$ & $.897 * *$ \\
\hline & Sig. (2-tailed) & .000 & & .000 & .000 & .000 \\
\hline & $\mathrm{N}$ & 30 & 30 & 30 & 30 & 30 \\
\hline \multirow{3}{*}{$\begin{array}{l}\text { Pernyataan } \\
7\end{array}$} & Pearson Correlation & $.694^{* *}$ & $.668 * *$ & 1 & $.774 * *$ & $.867^{* *}$ \\
\hline & Sig. (2-tailed) & .000 & .000 & & .000 & .000 \\
\hline & $\mathrm{N}$ & 30 & 30 & 30 & 30 & 30 \\
\hline \multirow{3}{*}{$\begin{array}{l}\text { Pernyataan } \\
8\end{array}$} & Pearson Correlation & $.762 * *$ & $.756 * *$ & $.774^{* *}$ & 1 & $.919 * *$ \\
\hline & Sig. (2-tailed) & .000 & .000 & .000 & & .000 \\
\hline & $\mathrm{N}$ & 30 & 30 & 30 & 30 & 30 \\
\hline \multirow{3}{*}{ Total } & Pearson Correlation & $.900 * *$ & $.897 * *$ & $.867 * *$ & .919 ** & 1 \\
\hline & Sig. (2-tailed) & .000 & .000 & .000 & .000 & \\
\hline & $\mathrm{N}$ & 30 & 30 & 30 & 30 & 30 \\
\hline
\end{tabular}

**. Correlation is significant at the 0.01 level (2-tailed).

*. Correlation is significant at the 0.05 level (2-tailed).

(Sumber : Olah data kuesioner SPPS for Windows)

Dari tabel di atas $\mathrm{r}$ hitung terletak pada kolom total "Person Correlation" pernyataan dinyatakan valid jika nilai $r$ hitung lebih besar dari $r$ tabel, untuk responden dengan jumlah $30 \mathrm{r}$ tabelnya adalah 0,463 pada taraf signifikansi $1 \%$, sedangkan $r$ hitung untuk semua pernyataan lebih besar dari pada $r$ tabel maka dapat dinyatakan pernyataan 5 (lima) sampai dengan 8 (delapan) dapat dinyatakan valid.

Tabel 3. Validitas Pernyataan Sembilan Sampai Dengan Duabelas Correlations

\begin{tabular}{|c|c|c|c|c|c|c|}
\hline & & $\begin{array}{l}\text { Pernyataan } \\
9\end{array}$ & $\begin{array}{c}\text { Pernyataan } \\
10\end{array}$ & $\begin{array}{c}\text { Pernyataan } \\
11\end{array}$ & $\begin{array}{c}\text { Pernyataan } \\
12\end{array}$ & Total \\
\hline \multirow{3}{*}{$\begin{array}{l}\text { Pernyataan } \\
9\end{array}$} & \multirow{3}{*}{$\begin{array}{l}\text { Pearson Correlation } \\
\text { Sig. (2-tailed) } \\
\text { N }\end{array}$} & 1 & .874 ** & .753 ** & $.804 * *$ & $.934^{* *}$ \\
\hline & & & .000 & .000 & .000 & .000 \\
\hline & & 30 & 30 & 30 & 30 & 30 \\
\hline \multirow{3}{*}{$\begin{array}{l}\text { Pernyataan } \\
10\end{array}$} & \multirow{3}{*}{$\begin{array}{l}\text { Pearson Correlation } \\
\text { Sig. (2-tailed) } \\
\text { N }\end{array}$} & .874 ** & 1 & .824 ** & .853 ** & $.964^{* *}$ \\
\hline & & .000 & & .000 & .000 & .000 \\
\hline & & 30 & 30 & 30 & 30 & 30 \\
\hline \multirow{3}{*}{$\begin{array}{l}\text { Pernyataan } \\
11\end{array}$} & \multirow{3}{*}{$\begin{array}{l}\text { Pearson Correlation } \\
\text { Sig. (2-tailed) } \\
\text { N }\end{array}$} & $.753 * *$ & $.824 * *$ & 1 & $.687^{* *}$ & $.876^{* *}$ \\
\hline & & .000 & .000 & & .000 & .000 \\
\hline & & 30 & 30 & 30 & 30 & 30 \\
\hline \multirow{3}{*}{$\begin{array}{l}\text { Pernyataan } \\
12\end{array}$} & \multirow{3}{*}{$\begin{array}{l}\text { Pearson Correlation } \\
\text { Sig. (2-tailed) } \\
\text { N }\end{array}$} & $.804^{* *}$ & .853 ** & $.687^{* *}$ & 1 & $.912^{* *}$ \\
\hline & & .000 & .000 & .000 & & .000 \\
\hline & & 30 & 30 & 30 & 30 & 30 \\
\hline \multirow[t]{3}{*}{ Total } & \multirow{3}{*}{$\begin{array}{l}\text { Pearson Correlation } \\
\text { Sig. (2-tailed) } \\
\text { N }\end{array}$} & $.934^{* *}$ & $.964^{* *}$ & $.876^{* *}$ & $.912^{* *}$ & 1 \\
\hline & & .000 & .000 & .000 & .000 & \\
\hline & & 30 & 30 & 30 & 30 & 30 \\
\hline
\end{tabular}

Analisis

**. Correlation is significant at the 0.01 level (2-tailed).

Pengaruh

85 
Tabel 4 Correlations

\begin{tabular}{|c|c|c|c|c|c|c|}
\hline & & $\begin{array}{c}\text { Pernyataan } \\
9\end{array}$ & $\begin{array}{c}\text { Pernyataan } \\
10\end{array}$ & $\begin{array}{c}\text { Pernyataan } \\
11\end{array}$ & $\begin{array}{c}\text { Pernyataan } \\
12\end{array}$ & Total \\
\hline \multirow{3}{*}{$\begin{array}{l}\text { Pernyataan } \\
9\end{array}$} & Pearson Correlation & 1 & $.874^{* *}$ & $.753 * *$ & $.804^{* *}$ & $.934^{* *}$ \\
\hline & Sig. (2-tailed) & & .000 & .000 & .000 & .000 \\
\hline & $\mathrm{N}$ & 30 & 30 & 30 & 30 & 30 \\
\hline \multirow{3}{*}{$\begin{array}{l}\text { Pernyataan } \\
10\end{array}$} & Pearson Correlation & $.874^{* *}$ & 1 & $.824^{* *}$ & .853 ** & $.964^{* *}$ \\
\hline & Sig. (2-tailed) & .000 & & .000 & .000 & .000 \\
\hline & $\mathrm{N}$ & 30 & 30 & 30 & 30 & 30 \\
\hline \multirow{3}{*}{$\begin{array}{l}\text { Pernyataan } \\
11\end{array}$} & Pearson Correlation & .753 ** & .824 ** & 1 & $.687 * *$ & $.876^{* *}$ \\
\hline & Sig. (2-tailed) & .000 & .000 & & .000 & .000 \\
\hline & $\mathrm{N}$ & 30 & 30 & 30 & 30 & 30 \\
\hline \multirow{3}{*}{$\begin{array}{l}\text { Pernyataan } \\
12\end{array}$} & Pearson Correlation & $.804^{* *}$ & $.853 * *$ & $.687^{* *}$ & 1 & $.912^{* *}$ \\
\hline & Sig. (2-tailed) & .000 & .000 & .000 & & .000 \\
\hline & $\mathrm{N}$ & 30 & 30 & 30 & 30 & 30 \\
\hline \multirow[t]{3}{*}{ Total } & Pearson Correlation & $.934^{* *}$ & $.964^{* *}$ & $.876^{* *}$ & $.912^{* *}$ & 1 \\
\hline & Sig. (2-tailed) & .000 & .000 & .000 & .000 & \\
\hline & $\mathrm{N}$ & 30 & 30 & 30 & 30 & 30 \\
\hline
\end{tabular}

*. Correlation is significant at the 0.05 level (2-tailed).

(Sumber: Olah data kuesioner SPPS for Windows)

Dari tabel di atas $r$ hitung terletak pada kolom total "Person Correlation" pernyataan dinyatakan valid jika nilai $\mathrm{r}$ hitung lebih besar dari $\mathrm{r}$ tabel, untuk responden dengan jumlah $30 \mathrm{r}$ tabel -nya adalah 0,463 pada taraf signifikansi 1\%, sedangkan $r$ hitung untuk semua pernyataan lebih besar dari pada $r$ tabel maka dapat dinyatakan pernyataan 9 (Sembilan) sampai dengan 12 (dua belas) dapat dinyatakan valid.

\section{Uji Reliabilitas}

Pengujian dilakukan dengan menggunakan SPSS versi 14.0. butir pernyataan yang sudah dinyatakan valid dalam uji validitas ditentukan reliabilitasnya dengan kriteria sebagai berikut:

Jika $\mathrm{r}$ alpha positif dan > $\mathrm{r}$ tabel maka reliabel.

Jika $\mathrm{r}$ alpha negatif dan $<\mathrm{r}$ tabel maka tidak reliabl

Tabel 5. Reliabilitas Pernyataan Satu Sampai Dengan Empat

\section{Reliability Statistics}

\begin{tabular}{llcc}
\hline $\begin{array}{l}\text { Cronbach } \\
\text { s Alpha }\end{array}$ & $\begin{array}{l}\text { Cronbach's Alpha } \\
\text { Standardized Items }\end{array}$ & Based on & N of Items \\
\hline .744 & .740 & 4 \\
\hline
\end{tabular}

\section{Sumber : Olah data kuesioner SPPS for Windows}

Suatu instrument pernyataaan dikatakan reliabel apabila memiliki cronbach alpha $>0,60$, dengan analisa SPSS diketahui nilai Cronboach's Alpha sebesar 0,744 , oleh karena itu $0,744>0,60$ dinyatakan data tersebut reliabel.

Musyafiq H.

Abdullah Salam

JURNAL EKONOMI SYARIAH INDONESIA, Volume V, No.1 Juni 2015 
Tabel 6. Reliabilitas Pernyataan Lima Sampai Dengan Delapan Reliability Statistics

\begin{tabular}{lccc}
\hline Cronbach's Alpha & $\begin{array}{c}\text { Cronbach's } \\
\text { Standardized Items }\end{array}$ & $\begin{array}{c}\text { Alpha } \\
\text { Stased }\end{array}$ & N of Items \\
\hline 917 & .918 & 4 \\
\hline
\end{tabular}

Sumber : Olah data kuesioner SPPS for Windows

Suatu instrument pernyataaan dikatakan reliabel apabila memiliki cronbach alpha $>0,60$, dengan analisa SPSS diketahui nilai Cronboach's Alpha sebesar 0,917, oleh karena itu $0,917>0,60$ dinyatakan data tersebut reliabel.

Tabel 7. Reliabilitas Pernyataan Sembilan Sampai Dengan Dua Belas Reliability Statistics

\begin{tabular}{lcc}
\hline Cronbach's Alpha & $\begin{array}{c}\text { Cronbach's } \\
\text { Standardized Items }\end{array}$ & N of Items \\
\hline .940 & .941 & 4 \\
\hline
\end{tabular}

Sumber : Olah data kuesioner SPPS for Windows

Suatu instrument pernyataaan dikatakan reliabel apabila memiliki cronbach alpha $>0,60$, dengan analisa SPSS diketahui nilai Cronboach's Alpha sebesar 0,940, oleh karena itu $0,940>0,60$ dinyatakan data tersebut reliabel.

\section{Analisis Regresi Linier Berganda}

Analisis regresi berganda digunakan untuk mengetahui seberapa besar pengaruh variabel bebas yang terdiri dari variabel syariah, pelayanan, produk, dan promosi terhadap variabel terikat yaitu keputusan nasabah terhadap permintaan pembiayaan mudharabah pada BMT Hidayah Umat Yogyakarta. Persamaan regresinya adalah sebagai berikut:

$$
Y=a+b_{1} X_{1}+b_{2} X_{2}
$$

Analisis regresi linier berganda dalam penelitian ini menggunakan program SPSS versi 16.0 for Windows yang dapat dilihat pada tabel berikut ini:

\section{Coefficients $^{a}$}

Tabel 8. Analisis Regresi Linier Berganda

\begin{tabular}{llccccc}
\hline Model & & \multicolumn{2}{c}{$\begin{array}{c}\text { Unstandardized } \\
\text { Coefficients }\end{array}$} & $\begin{array}{c}\text { Standardized } \\
\text { Coefficients }\end{array}$ & $\mathrm{t}$ & Sig. \\
\cline { 3 - 5 } & & $\mathrm{B}$ & Std. Error & Beta & & \\
\hline \multirow{2}{*}{1} & (Constant) & 7.703 & 1.537 & & 5.011 & .000 \\
& Pendidikan & .270 & .130 & .232 & 2.080 & .040 \\
& Pekerjaan & .249 & .114 & .244 & 2.180 & .032 \\
\hline
\end{tabular}

a. Dependent Variable: Pengetahuan Produuk Perbankan Syari'ah.

(Sumbe: olah data kuesioner SPSS for Windows)

Analisis

Pengaruh
Berdasarkan hasil pengolahan data seperti terlihat dalam tabel 7 pada kolom kedua (Unstandardized coefesients) bagian B pada baris pertama diperoleh model persamaan regresi linier bergandanya adalah sebagai berikut:

$$
\mathrm{Y}=7,703+0,270 \mathrm{X}_{1}+0,249 \mathrm{X}_{2}
$$


Dimana:

$\mathrm{Y} \quad=$ Pengetahuan Produk Perbankan Syariah

$\mathrm{X}_{1} \quad=$ Pendidikan

$\mathrm{X} 2=$ Pekerjaan

a $\quad$ Nilai Konstanta

$\mathrm{b} \quad=$ Koefesien Regresi

Berdasarkan hasil pengolahan data pada tabel 4.11 adalah:

X1: Ketika pendidikan masyarakat semakin tinggi atau mengalami peningkatan maka pengetahuan akan produk perbankan syari' ah mengalami peningkatan.

X2: Ketika bidang pekerjaan masyarakat semakin baik maka pengetahuan produk perbankan syari'ah mengalami peningkatan.

\section{Pengujian Hipotesis.}

\section{Uji-t (uji parsial)}

Nilai $\mathrm{t}$ diperoleh dengan menggunakan bantuan program SPSS 16.0 for Windows seperti terlihat pada tabel 4.12 berikut ini.

\section{Coefficients $^{\mathrm{a}}$}

Tabel 9. Hasil Uji T-hitung

\begin{tabular}{lllllll}
\hline & & \multicolumn{2}{l}{$\begin{array}{l}\text { Unstandardized } \\
\text { Coefficients }\end{array}$} & \multicolumn{2}{l}{$\begin{array}{l}\text { Standardized } \\
\text { Coefficients }\end{array}$} & \\
\cline { 2 - 4 } Model & $\mathrm{B}$ & Std. Error & Beta & $\mathrm{t}$ & Sig. \\
\hline 1 & (Constant) & 7.703 & 1.537 & & 5.011 & .000 \\
& Pendidikan & .270 & .130 & .232 & 2.080 & .040 \\
& Pekerjaan & .249 & .114 & .244 & 2.180 & .032 \\
\hline
\end{tabular}

a. Dependent Variable: PengetahuanProduk Perbankan Syari'ah.

(Sumber: olah data kuesioner SPSS for Windows).

Pada tabel 8 dapat diketahui bahwa nilai t-hitung untuk variabel pendidikan (X1) adalah 2.080; variabel pekerjaan (X2) adalah 2.180. Berdasarkan kriteria uji hipotesis maka dapat disimpulkan:

Variabel Pendidikan (X1)

Nilai t hitung dari variabel ini adalah 2.080 dengan tingkat signifikan 0.040. Dengan tingkat signifikan level 95\% maka dapat diketahui a $=0,05$. Berdasarkan kriteria uji hipotesis maka dapat dinyatakan bahwa tingkat signifikan dari variabel X1 pada table tersebut diatas adalah $0,040<0,05$, dengan demikian variabel $\mathrm{X} 1$ (pendidikan) dapat dinyatakan signifikan terhadap pengetahuan produk perbankan syari'ah.

Variabel Pekerjaan (X2)

Nilai t hitung dari variabel ini adalah 2.180 dengan tingkat signifikan 0.032. Dengan tingkat signifikan level 95\% maka dapat diketahui a $=0,05$. Berdasarkan kriteria uji hipotesis maka dapat dinyatakan bahwa tingkat signifikan dari variabel X2 pada tabel tersebut diatas adalah 0,032<0,05, dengan demikian variabel X2 (pekerjaan) dapat dinyatakan signifikan terhadap pengetahuan produk perbankan syari'ah

Musyafiq $\mathrm{H}$.

Abdullah Salam

JURNAL EKONOMI SYARIAH INDONESIA, Volume V, No.1 Juni 2015 


\section{Uji Simultan dengan F statistik (ANOVA)}

Hasil uji F dengan SPSS 14 for windows adalah sebagai berikut:

Tabel 10. Uji statistik F ANOVA ${ }^{b}$

ANOVA $^{b}$

\begin{tabular}{lllcccc}
\hline \multicolumn{1}{l}{ Model } & Sum of Squares & df & Mean Square & F & Sig. \\
\hline 1 & Regression & 174.264 & 2 & 87.132 & 9.646 & $.000^{\mathrm{a}}$ \\
\cline { 3 - 7 } & Residual & 831.041 & 92 & 9.033 & & \\
\cline { 2 - 6 } & Total & 1005.305 & 94 & & & \\
\hline
\end{tabular}

a. Predictors: (Constant), Pekerjaan, Pendidikan

b. Dependent Variable: PengetahuanProduuk.

Sumber: olah data kuesioner SPSS for Window

Pada tabel di atas dapat dilihat bahwa hasil signifikan uji $\mathrm{F}$ untuk pengetahuan produk perbankan syari'ah sebesar 0,000. Hasil uji tersebut berada di bawah nilai alpha 0,05 , dengan demikian dapat dinyatakan bahwa berdasarkan uji simultan variabel X1(pendidikan) dan X2 (pekerjaan) secara bersama-sama berpengaruh signifikan terhadap variabel $Y$ (pengetahuan produk perbankan syari'ah).

Uji determinan $\left(R^{2}\right)$

Tabel 11. Uji Determinan

Model Summary

\begin{tabular}{lllll}
\hline Model & $\mathrm{R}$ & $\mathrm{R}$ Square & $\begin{array}{l}\text { Adjusted } \mathrm{R} \\
\text { Square }\end{array}$ & $\begin{array}{l}\text { Std. Error of the } \\
\text { Estimate }\end{array}$ \\
\hline 1 & $.416^{\mathrm{a}}$ & .173 & .155 & 3.00550 \\
\hline
\end{tabular}

a. Predictors: (Constant), Pekerjaan, Pendidikan

b. Dependent Variabel: Pengetahuan Produk Perbankan Syari'ah

Dari hasil statistik diperoleh koefesien determinasi $\mathrm{R}^{2}=0,173$ yang berarti $17,3 \%$ dari variasi variabel terikat (dependen) dapat dijelaskan oleh variasi variabel bebasnya (independen), sedangkan 82,7\% lainnya dijelaskan oleh variasi variabel lain di luar penelitian ini.

\section{KESIMPULAN}

Berdasarkan pada analisis yang telah dilakukan terhadap data hasil penelitian, maka dapat diambil kesimpulan sebagai berikut:

Dari hasil Uji Validitas dan Reliabilitas dengan menggunakan SPSS dapat diketahui sebagai berikut:

Untuk uji validitas dapat dinyatakan semua butir kuesioner adalah valid, karena pengujian validitas menunjukan $\mathrm{r}$ hitung $>$ dari $\mathrm{r}$ tabel dan pada tingkat signifikan $<0,05$.

Untuk uji reliabilitas dapat dinyatakan semua butir kuesioner adalah

Analisis reliabel, karena pengujian reliabilitas Cronbach's Alpha $>0,60$.

Pengaruh 


\section{Hasil pengujian secara parsial}

Dari hasil perhitungan dengan program SPSS diketahui bahwa variabel X1 memiliki tingkat signifikan sebesar 0,040, jika dibandingkan dengan tingkat signifikan level sebesar $95 \%$ atau 0,05, maka X1 0,040<0,05 sehingga dapat dinyatakan bahwa variabel X1 (pendidikan) berpengaruh signifikan terhadap variabel Y (pengetahuan produk perbankan syari'ah).

Dari hasil perhitungan dengan program SPSS diketahui bahwa variabel X1 memiliki tingkat signifikan sebesar 0,030, jika dibandingkan dengan tingkat signifikan level sebesar 95\% atau 0,05, maka X1 0,032<0,05 sehingga dapat dinyatakan bahwa variabel X2 (pekerjaan) berpengaruh signifikan terhadap variabel Y (pengetahuan produk perbankan syari'ah).

\section{Hasil Pengujian Secara Simultan}

Bahwa nilai signifikan $\mathrm{F}$ adalah 0,000, jika dibandingkan dengan tingkat signifikan level sebesar $95 \%$ atau 0,05, maka 0,000 < 0,05 sehingga dapat dinyatakan bahwa variabel X1(pendidikan) dan X2 (pekerjaan) secara bersama- sama atau simultan berpengaruh secara signifikan terhadap variabel Y (pengetahuan produk perbankan syari'ah).

Berdasarkan hasil statistik menggunakan program SPPS 16.0 for Windows variabel X1 (pendidikan) berpengaruh terhadap pengetahuan produk perbankan syari' ah yang artinya semakin tinggi tingkat pendidikan seseorang maka semakin baik dan faham terhadap pengetahuan produk perbankan syari' ah dan sebaliknya semakin rendah tingkat pendidikan seseorang maka semakin buruk terhadap pengetahuan produk perbankan syari'ah. Sedangkan berdasarkan variabel X2 (pekerjaan) bahwa kepala kelurga khususnya di Padukuhan Krapyak Kulon yang memiliki status pekerjaan wiraswasta atau yang berpenghasilan baik mereka lebih sering berhubungan dengan produk perbankan syari'ah sehingga mengerti tentang produk perbankan syari'ah.

\section{DAFTAR PUSTAKA}

Ahmadi, Abu, \& Uhbiyati, Nur, Ilmu Pendidikan,1991, Jakarta: PT.Melton Putra

Alma, Buchari \& Donni, Juni Priansa, 2009, Manajemen Bisnis Syari'ah, Bandung: Penerbit Alfabeta

Antonio, Muhammad Syafi'I, 2001, Bank Syari'ah: Dari Teori ke Praktik, Jakarta: Gema Insani Press

Arikunto, Suharsimi, 2002, Prosedur Penelitian suatu Pendekatan Praktik, Jakarta: Rineka Cipta

Ash-Shawi, Muhammad Shalah Muhammad, 2008, Problematika Investasi Pada Bank Islam Solusi Ekonomi Islam, Jakarta: Migunani

Departemen Agama RI, 2007, Al-Qur'an dan Terjemahnya, Bandung: CV.Penerbit Jumanatul Ali-Art (J-ART)

Ghazali, Imam, 2005, Analisis Multivariate dengan program SPSS, Semarang: Badan Penerbit Universitas Diponegoro

Musyafiq $\mathrm{H}$.

Abdullah Salam

http://www.scribd.com/doc/50456805/indikator-pendidikan, Senin, 10 Juni 2013, Pukul 21:49 WIB 
Husein, Umar, 2005, Metodologi Penelitian Untuk Skripsi Dan Tesis Bisnis, Jakarta: PT Raja Grafindo Persada

Lewis, Marvyin K., \& Latifa.M., Algaoud, 2001, Perbankan Syari'ah: Prinsip, Praktik, dan Prospek, Jakarta: PT.Serambil Ilmu Semesta

Machfoedz, Ircham, 2010, Metodologi penelitian Kuantitatif $\mathcal{E}$ Kualitatif Bidang Kesehatan, Keperawatan, kebidanan, kedokteran, Yogyakarta: Penerbit Fitramaya

Muhammad, 2005, Manajemen Bank Syari'ah Edisi Revisi, Yogkarta: Unit Penerbit dan Percetakan (UPP) AMPYKPN

Nisak, Arifatun, 2012, "Pengaruh Kelompok Acuan Dan Pengetahuan Tentang Perbankan Sya'ariah Terhadap Minat Menabung Di Perbankan Syari'ah Semarang " dalam Jurnal Literasi, 10 (4) 3, Semarang

Notoatmodjo, Sokidjo, 2003, Pendidikan Dan Perilaku Kesehatan, Jakarta: PT Rineka Cipta

$$
\text { ,2010, Ilmu Perilaku Kesehatan, Jakarta: PT. Rineka Cipta }
$$

Purwoto, Agus, Panduan Laboratorium Statistik Inferensia, Jakarta: PT Grasindo

Rencana Pembangunan Permukiman (RPP) Desa Panggungharjo 2009-2014, Kecamatan Sewon Kabupaten Bantul Proinsi D.I. Yogyakarta

Riduwan \& Sunarto, 2011, Pengantar Statistika Untuk Penelitian: Pendidikan, Sosial, Komunikasi, Ekonomi, dan Bisnis, Bandung: Penerbit Alfabeta

Sugiyono, 2011, Metode Penelitian Kuantitatif Kualitatif dan RED, Bandung: Penerbit Alfabet

Sungkar, Saleha, et, al, 2010, "Pengaruh Penyuluhan Terhadap Tingkat Pengetahuan Masyarakat Dan Kepadatan Aedes aegypty Di Kecamatan Bayah, Provinsi Banten" dalam Jurnal Literasi , 28 (4) 3 Jakarta: Departemen Parasitologi, Fakultas Kedokteran Universitas Indonesia

Supardi, 2005, Metodologi Penelitian Ekonomi dan Bisnis, Yogyakarta: UII Press

Suseno, Priyonggo \& Heri, Sudarsono, 2004, Undang-undang (UU), Peraturan Bank Indonesia (PBI) dan Surat Keputusan Direksi BI (SK-DIR) Tentang Perbankan Syari'ah, Yogyakarta: UII Press

Undang-undang Republik Indonesia Nomor 13 Tahun 2003 Tentang Ketenagakerjaan

Analisis

Pengaruh 